\title{
Egg distribution in the large copper butterfly Lycaena dispar batavus (Lepidoptera: Lycaenidae): Host plant versus habitat mediated effects
}

\author{
MARK R. WEBB ${ }^{1}$ and ANDrew S. PULLIN ${ }^{2}$ \\ ${ }^{1}$ Biology Division, School of Sciences, Staffordshire University, College Road, Stoke on Trent, ST4 2DE, UK \\ ${ }^{2}$ School of Biological Sciences, University of Birmingham, Edgbaston, Birmingham, B15 2TT, UK; e-mail: a.s.pullin@bham.ac.uk
}

Keywords. Lepidoptera, Lycaenidae, Lycaena dispar batavus, oviposition, insect-plant relationships, Rumex hydrolapathum, herbivory, consumer and host, butterfly, conservation biology, wetlands

\begin{abstract}
The large copper butterfly, Lycaena dispar batavus, a subspecies of much conservation interest, is host-specific to the great water dock, Rumex hydrolapathum, but little is known of the relationship between herbivore and host in wild populations. This study investigated the distribution of both $R$. hydrolapathum plants and $L$. d. batavus eggs in four different habitat types within the Weerribben National Park, The Netherlands, during the summer of 1993. As expected, host plant distribution strongly influenced that of its herbivore. Further, both species had significantly aggregated distributions, and that of $R$. hydrolapathum was in agreement with the negative binomial model. Host plant selection for oviposition showed no significant relationship with physical plant characteristics, such as plant height and the number of leaves, and at the scale studied, habitat type was of only limited influence. The possible influence of the vegetational architecture surrounding host plants is discussed.
\end{abstract}

\section{INTRODUCTION}

Host plant selection in the Lepidoptera operates at different scales, and females may choose particular habitats/ micro-habitats, species or other taxa, individuals, or specific plant parts (e.g. Porter, 1992). Host location can involve chemical cues, (e.g. Courtney, 1988), however visually-recognised physical cues such as leaf shape (e.g. Rausher, 1978; Stanton, 1982) play a major role in most species (Chew \& Robbins, 1984; Thompson \& Pellmyr, 1991; Renwick \& Chew, 1994). Indeed, many studies of butterfly oviposition have found that large, visually apparent host plants are selected preferentially (e.g. Wiklund, 1977; Warren, 1984), although the opposite may occur (e.g. Dennis, 1985). Further, females may discriminate between individuals of a host species via concentration of secondary plant metabolites (e.g. Ehrlich \& Raven, 1965; Baylis \& Pierce, 1991; also see Oyeleye \& Zalucki, 1990), leaf quality (e.g, Mattson, 1980; Scriber \& Slansky, 1981), presence of con-specific or other eggs (e.g. Rothschild \& Schoonhoven, 1977; Rausher, 1979) or herbivory from other invertebrates (e.g. McKay, 1991).

The large copper butterfly, particularly the north-west European race Lycaena dispar batavus (Oberthür), has been the subject of previous ecological research, primarily because of its conservation interest (e.g. Pullin et al., 1995; Pullin, 1997; Webb \& Pullin, 1997). Its only host plant, Rumex hydrolapathum Hudson, is characteristic of a broad range of wetland habitats, though it is particularly abundant along water edges (Duffey, 1968; Bink, 1986; Webb, 1995). R. hydrolapathum plants growing in these waterside situations often appear to be more vigorous, taller and have a larger number of leaves than plants growing away from waterways and within fen vegetation itself (e.g. Duffey, 1968; Bink, 1986). However, previous observations have shown that females tend to avoid ovipositing on waterside plants (see Committee, 1929; Ellis, 1951; Duffey, 1968). There is, therefore, a possible mismatch between those host plants selected for oviposition by females, and those that are the most suitable for larval growth and performance. This is in contrast to the findings of studies such as Leather (1985), but has been found repeatedly in other studies of Lepidoptera (Chew, 1977). However, these initial observations of waterside plant avoidance took place in (re-)introduced British colonies of $L . d$. batavus, and may not reflect the situation in wild populations.

The objectives of this study were threefold: (1) to record the distribution and abundance of $L$. d. batavus eggs in a wild population in the Weerribben National Park, The Netherlands - site of the largest remaining native population; (2) to investigate possible relationships between host plant characteristics such as size and site selection for oviposition, and; (3) to compare plant selection in different habitat types, subject to contrasting management regimes, in order to elucidate larger-scale effects of host utilization.

\section{MATERIAL AND METHODS}

Lycaena $d$. batavus eggs were recorded on $R$. hydrolapathum plants along transect walks $(\mathrm{N}=35$, mean length $=182.26 \pm$ $9.72 \mathrm{~m}$ ) within the Weerribben, during the summer of 1993. Transect locations were selected systematically, to provide replicated sampling of the different habitat types present at the site, including: reed-fields $(\mathrm{N}=10$, mean length $=163.8 \pm 11.89 \mathrm{~m})$; reed-field ribben (linear strips of vegetation surrounding reedfields: $\mathrm{N}=4$, mean length $=194.75 \pm 12.58 \mathrm{~m})$, hay-fields $(\mathrm{N}=$ 15 , mean length $=201.47 \pm 17.91 \mathrm{~m}$ ) and watersides [mostly linear edges to reed-fields (with or without ribben): $\mathrm{N}=6$, mean length $=156.67 \pm 23.72 \mathrm{~m}]$. These habitat types also reflect different site management practices, as reed-fields are cut in winter, hay-fields and reed-field ribben in summer, and watersides in either summer or winter.

Repeatability was ensured by making all transects linear and in parallel to the nearest waterway. Distance from the waterway was 
TABLE 1. The abundance and density of Lycaena dispar batavis eggs along transects $(\mathrm{N}=35)$ in different habitat types within the Weerribben National Park in 1993, including reed-fields $(\mathrm{N}=10)$; reed-field ribben $(\mathrm{N}=4)$, hay-fields $(\mathrm{N}=15)$ and watersides $(\mathrm{N}=$ 6).

\begin{tabular}{lllllrl}
\hline Transect site location & Habitat type & $\begin{array}{l}\text { No. of } \\
\text { quadrats }\end{array}$ & $\begin{array}{l}\text { No. of Rumex } \\
\text { plants }\end{array}$ & $\begin{array}{l}\text { No. of plants with Total no. } \\
\text { eggs }\end{array}$ & $\begin{array}{l}\text { Mean no. of eggs } \\
\text { per plant }\end{array}$ \\
\hline Lokkenvaart (North) & Hayfield ditch & 248 & 93 & $23(24.47 \%)$ & 189 & 2.03 \\
Lokkenvaart (South) & Hayfield ditch & 130 & 24 & $13(54.16 \%)$ & 96 & 4.00 \\
Meentegat & Reedfield & 204 & 39 & $9(23.07 \%)$ & 23 & 0.59 \\
Meentegat & Reedfield ribben & 207 & 35 & $11(31.43 \%)$ & 24 & 0.69 \\
Kroonegat & Reedfield waterside & 95 & 13 & $2(15.38 \%)$ & 11 & 0.85 \\
\hline
\end{tabular}

recorded, and was partially dependant upon field conditions, e.g. if a waterside strip had been uncut for a number of years, it would be impossible to survey within such an area, and one would have to move further into the field. The actual length of a transect was also largely dependent on the site details, usually the width of the field in question. On the whole, suitable landmarks (windmills, mooring points, solitary trees) were used to enable exact repetition of the transect in any future studies; transects were only sampled once here. Care was taken not to bias sampling by only choosing representative areas (e.g. ignoring scrubby or atypical patches), and conversely not to over-emphasize atypical areas. All transects were in sunny, as opposed to shaded positions.

Transect walks were divided into contiguous $1 \mathrm{~m}^{2}$ quadrats and within each quadrat the following were recorded: (1) number of individual plants of $R$. hydrolapathum present; (2) plant height (this was recorded as the height of the tallest plant part, which was the flowering stem on plants with an inflorescence, and the longest leaf on non-flowering plants); (3) number of leaves (in non-flowering plants the total number of leaves was recorded with any plants bearing a flowering stem, the number of basal leaves was recorded, ignoring any stem leaves or bracts present above ground on the stem itself); (4) number of $L$.d. batavus eggs present on adaxial and abaxial (i.e. upper and lower) surfaces of each leaf; (5) size of egg clusters [L. d. batavus eggs are distinctive and easily recognized (see Frohawk, 1929) - it was assumed that eggs very closely adjacent to each other, (usually touching each other in small groups or strings), were deposited during a single visit by a female].

\section{RESULTS}

\section{Population distribution in $R$. hydrolapathum and $L$. $d$. batavus}

The population distribution of $R$. hydrolapathum along an example transect (Lokkenvaart North - selected because of its large $\mathrm{N}$ value) was significantly aggregated, as shown by the index of dispersion test $\left(\mathrm{I}=1.84, \chi^{2}=453.81, \mathrm{z}=\right.$ $7.92, P=<0.05$ ) (Krebs, 1989). Further, it was concordant with (i.e. it did not differ significantly from) a negative binomial distribution $\left(\chi^{2}=4.10, \mathrm{df}=3, P=>0.05\right.$; see Table 1). $k=0.4178$, as calculated by the maximum likelihood method (Krebs, 1989). The distribution of $L$. d. batavus eggs (using the number of eggs per plant) along the same transect was also significantly aggregated $\left(\mathrm{I}=38.36, \chi^{2}=\right.$ $3529.49, \mathrm{z}=70.49, P=<0.05$ ) (Krebs, 1989). It was however, not in agreement with the negative binomial $\left(\chi^{2}=\right.$ 26.42, $\mathrm{df}=4, P=<0.05$; see Table 1) (Krebs, 1989).

Combining data for all transects showed that $69.8 \%$ of eggs were laid on the adaxial surfaces, i.e. uppersides, of leaves and $30.2 \%$ were laid on abaxial surfaces, i.e. undersides, of leaves. In terms of egg cluster size, $51.2 \%$ of eggs were laid as singletons, $30.2 \%$ as pairs, $10.5 \%$ as trios, and $8.1 \%$ as groups of four or more. The largest cluster found consisted of six eggs.

\section{Host plant selection for oviposition and plant characteristics}

The non-parametric egg distribution data required transformation before regression analysis, and for this the derived statistic of $(1 / x+1)$ was used as it proved to be in agreement with a normal distribution. The plant attributes that were to be tested for regression with the egg distribution data agreed with a normal distribution without transformation. The data were then analyzed using multiple regression analysis, and no significant relationship was found between the number of eggs present on a plant, and either of the plant characteristics tested (plant height, $P=$ 0.716 ; number of leaves, $P=0.917$ ).

\section{Host plant selection for oviposition in different habitat types}

Of the 35 transects that were carried out in the Weerribben, only five contained $R$. hydrolapathim plants with $L$. d. batavus eggs. Table 1 shows the abundance and density of eggs found along these transects, and also shows that three habitat types were represented, i.e. eggs were found in reed-fields, reed-field ribben, and along watersides, but not in hay-fields per se.

An overall statistical comparison of the number of eggs per plant showed that this differed significantly between these five different transects (Kruskall-Wallis, $\mathrm{H}=12.85$, df $=4, P=0.012$ ). Preliminary individual comparisons between transects were then carried out using the MannWhitney $U$ test, the results of which are given in Table 2 . Although multiple testing in this way might lead to Type 1 errors, the emergent pattern is clear from visual examination of the data, and so this simple method of analysis was preferred (se e Zar, 1996). The two waterside transects within the Lokkenvaart hay-field (Lokkenvaart North and South) contained the highest density of eggs (mean number of eggs per plant 2.03 and 4.00 , respectively), in fact Lokkenvaart south had a significantly higher number of eggs than any other transect. Apart from this difference, however, there were no significant differences, in egg number per plant, in comparisons between any of the other transects. 
TABLE 2. Statistical comparison of the number of eggs per plant along different transects in the Weerribben National Park in 1993. Comparisons were carried out using the Mann-Whitney $U$ test. Where two transects differ significantly $(p<0.05)$, $p$ values are given in bold.

\begin{tabular}{lcccc}
\hline & Lokkenvaart North & Lokkenvaart South & Meentegat Reedfield & Meentegat Reedfield Ribben \\
\hline Lokkenvaart South & $\mathbf{p}=\mathbf{0 . 0 0 2}$ & - & - & - \\
Meentegat Reedfield & $\mathrm{p}=0.762$ & $\mathbf{p}=\mathbf{0 . 0 0 4}$ & - & - \\
Meentegat Reedfield Ribben & $\mathrm{p}=0.596$ & $\mathbf{p}=\mathbf{0 . 0 1 8}$ & $\mathrm{p}=0.458$ & - \\
Kroonegat Waterside & $\mathrm{p}=0.516$ & $\mathbf{p}=\mathbf{0 . 0 3 2}$ & $\mathrm{p}=0.668$ & $\mathrm{p}=0.381$ \\
\hline
\end{tabular}

\section{DISCUSSION}

\section{Host plant and egg distributions}

Rumex hydrolapathum host plants were significantly aggregated in distribution, and their distribution was concordant with one predicted by a negative binomial model. The distribution of $L$. d. batavus eggs along our example transect was also significantly aggregated, but was not adequately described by the negative binomial, which contrasts with some earlier findings with insect populations (Bliss \& Fisher, 1953; Cain et al., 1985; Southwood, 1976). This is probably because a small number of host individuals received a very large number of eggs, up to a maximum of 73 eggs per plant. Duffey (1968) showed that the size of a $R$. hydrolapathum plant influences the number of larvae it can support to maturity, and it is unlikely that all the larvae resulting from 73 eggs could survive on a single host plant, even when allowing for high larval mortality (Webb \& Pullin, 1996) and/or a very large host plant.

Many butterfly species employ con-specific egg recognition and avoidance behaviour to avoid an isolated foodplant receiving more eggs than it can support to maturity (Rausher, 1979; Dempster, 1992; Vasconcellos-Neto \& Monteiro, 1993). Likewise, ovipositing females may choose plants exhibiting lower levels of inter-specific herbivory (see McKay, 1991; also Damman, 1993), although there are studies that show no egg avoidance mechanism (e.g. Singer \& Mandracchia, 1982), and anecdotal field observations suggest that this is so with $L . d$. batavus (M.R.Webb, pers. observ.). Further, according to Rausher's hypothesis (1979), as R. hydrolapathum plants can support $>2$ larvae to maturity (Duffey, 1968), no avoidance should be expected. As single oviposition events in $L$. d. batavus never resulted in $>6$ eggs, the data suggest that egg loads of greater than this must represent repeated visits to certain plants by one or more females, while other plants remain unused.

\section{Host plant effects on oviposition}

Numerous studies have found that host selection for oviposition is linked with physical plant parameters such as size (e.g. Chew \& Robbins, 1984). For example, marsh fritillary Eurodryas aurinia, females select larger than average host plants for oviposition (Porter, 1992). In contrast, Dennis (1985), recorded that smaller plants were preferred in the green-veined white Pieris napi. The data from our study are therefore in contrast to earlier findings, as there was no significant relationship between the host plant characteristics measured, i.e. plant height and number of leaves, and selection for oviposition by $L$. $d$. batavus females, al- though more eggs were laid on the upper (cf. under) surfaces of leaves.

It is however possible that biochemical characteristics not measured in this study influence host selection. For example leaf nitrogen can have a demonstrable role (Stamp \& Bowers, 1990; Thomas \& Hodkinson, 1991; Slansky, 1993), although it does not influence monarch butterflies, Danaus plexippus. Females of $D$. plexippus did differentially select plants with lower levels of cardenolides, secondary compounds associated with plant defences (Oyeyele \& Zalucki, 1990; also see Rausher, 1981; Baylis \& Pierce, 1991; McKay, 1991; Ravenscroft, 1994). However, as plant chemical characteristics (such as plant nitrogen and secondary plant metabolite concentrations) often correlate with plant size or age (e.g. Mattson, 1980; Crawley, 1983), a lack of a relationship between host selection and physical characteristics may suggest that selection is not linked to chemical characteristics either.

\section{Habitat mediated effects}

In the absence of con-specific egg avoidance behaviour, it is predictable that in certain situations plants will receive large numbers of eggs, especially when isolated (e.g. Jones, 1977; Mackay \& Singer, 1982; Rausher, 1983; Sóberon et al., 1988), or if not isolated, then at the edge of a clump (see Courtney \& Courtney, 1982; Courtney \& Duggan, 1983; Courtney, 1986), or visually apparent (e.g. Cromartie, 1975; Wiklund, 1984; McKay, 1991) and in a sunny position (e.g. Gossard \& Jones, 1977; Thomas, 1985; Shreeve, 1986; Warren, 1995). These factors may well contribute to an explanation for the distribution of eggs of $L$. d. batavus, and we hypothesize that habitat characteristics are a more important influence than hostplant selection in oviposition site selection in $L$. d. batavus.

\section{Host plant selection in different habitat types}

In contrast to earlier observations with (re-)introduced populations of $L$. d. batavus in Britain, waterside plants were not avoided by ovipositing females. Further evidence of this is provided by Pullin (1997). This may have consequences for subsequent larval survival, as Webb \& Pullin $(1996,1998)$ showed that overwintering larvae on waterside plants are more susceptible to winter flooding, although survival is comparable with other habitat types in the absence of flooding events (Pullin, 1997). Indeed, at the scale studied, habitat type appeared to be of limited influence on host plant selection, with eggs being widely distributed throughout three out of four habitat types (also see Pullin, 1997). 
We conclude with an hypothesis that habitat mediated effects are the major determinants of host plant selection for oviposition in L. d. batavus, but that these are not simply linked to habitat type. Further, it may be that the physical structure of surrounding vegetation, i.e. vegetational architecture, is more important that the habitat type per se, and that favourable structures can be achieved using different management techniques in different habitat types. For instance, a favourable vegetational architecture may be one that creates the right blend of sunshine and shelter, and therefore warmer microclimates, as observed by Warren (1995), and it may be that these are actively sought by females, especially in years of poor summer weather. All of our transects were located in sunny as opposed to shady conditions, and eggs have never been found on totally shaded plants (also see Pullin, 1997). More than any other transect, the one along Lokkenvaart South, which received by far the highest density of eggs, seemed to fit this description; conditions appeared to be sheltered yet open and particularly sunny. Individual plants here received up to 73 eggs and must have been selected repeatedly. Direct observation of female oviposition behaviour and of leaf surface temperatures will prove or disprove this hypothesis, but the nature of the wetland terrain, combined with the large areas of potential habitat, are likely to hinder future work.

ACKNOWLEDGEMENTS. This research was supported by a Keele University Studentship (MRW), Hugh Leech Travelling Scholarship (MRW), English Nature's Species Recovery Programme (ASP) and Butterfly Conservation (ASP). We would also like to thank J. van der Made and C. van Swaay of de Vlinderstichting (Dutch Butterfly Foundation) and E. Jans and B. Mülder of Statsbosbeheer, de Weerribben (Netherlands State Forestry Service).

\section{REFERENCES}

Baylis M. \& Pierce N.E. 1991: The effect of hostplant quality on the survival of larvae and oviposition by adults of an anttended lycaenid butterfly, Jalmenus evagorus. Ecol. Entomol. 16: $19 \mathrm{pp}$

BINK F.A. 1986: Acid stress in Rumex hydrolapathum (Polygonaceae) and its influence on the phytophage Lycaena dispar (Lepidoptera: Lycaenidae). Oecologia 70: 447-451.

BLISS C.I. \& FisHeR R.A. 1953: Fitting the negative binomial distribution to biological data. Biometrics 9: 176-200.

Cain M.L., Eccleston J. \& Kareiva P.M. 1985: The influence of food plant dispersion on caterpillar searching success. Ecol. Entomol. 10: 17 pp.

CHEw F.S. 1977: Coevolution of pierid butterflies and their cruciferous foodplants. II. The distribution of eggs on potential foodplants. Evolution 21: 568-579.

Chew F.S. \& Robins R.K. 1984: Egg laying in butterflies. In Vane-Wright R.I. \& Ackery P.R. (eds): The Biology of Butterflies. Princeton University Press, Princeton, New Jersey.

Committee 1929: Report of the committee appointed by the Entomological Society of London for the protection of British Lepidoptera. Proc. Entomol. Soc. Lond. 4: 53-68.

Courtney S.P. 1986: The ecology of Pierid butterflies: dynamics and interactions. $A d v$. Ecol. Res. 15: 15-131.

COURTNEY S.P. 1988: Oviposition on peripheral hosts by dispersing Pieris napi (L.) (Pieridae). J. Res. Lepid. 26: 58-63.
Courtney S.P. \& Courtney S. 1982: The "edge-effect" in butterfly oviposition: causality in Anthocharis cardamines and related species. Ecol. Entomol. 7: 131-137.

CourTnEY S.P. \& DUGGan A.E. 1983: The population biology of the orange tip butterfly, Anthocharis cardamines, in Britain. Ecol. Entomol. 8: 271-281.

Crawley M.J. 1983: Herbivory, The Dynamics of Animal-Plant Interactions. Studies in Ecology 10. Blackwell Scientific, Oxford, $437 \mathrm{pp}$.

Cromartie W.J. 1975: The effect of stand size and vegetation background on the colonization of cruciferous plants by herbivorous insects. J. Appl. Ecol. 12: 517-533.

Damman H. 1993: Patterns of interaction among herbivore species. In Stamp N.E. \& Casey T.M. (eds): Caterpillars - Ecological and Evolutionary Constraints on Foraging. Chapman and Hall, London.

DEMPSTER J.P. 1992: Evidence of an ovipositiondeterring pheromone in the orangetip butterfly, Anthocharis cardamines L. Ecol. Entomol. 17: 83-85.

DenNIS R.L.H. 1985: Small plants attract attention! Choice of egg laying sites in the green-veined white butterfly (Artoegia napi) (L.) (Lep: Pieridae). Bull. Amat. Entomol. Soc. 44: $77-82$.

DufFey E. 1968: Ecological studies on the large copper butterfly, Lycaena dispar batavus, at Woodwalton Fen National Nature Reserve. J. Appl. Ecol. 5: 69-96.

Ehrlich P.R. \& RaveN P.H. 1965: Butterflies and plants: a study in coevolution. Evolution 18: 586-608.

Eluis E.A. 1951: The introduction of the large copper butterfly (Lycaena dispar batavus. Oberthur) at Wheatfen broad, Norfolk. Trans. Norfolk Nat. Soc. 17: 84-90.

FroHaWk F.W. 1924: The Natural History of British Butterflies. Vol. II. Hutchinson, London.

GOSSARD T.W. \& JONES R.E. 1977: The effects of age and weather on egglaying in Pieris rapae L. J. Appl. Ecol. 14: $65-71$

JONES R.E. 1977: Movement patterns and egg distribution in cabbage butterflies. J. Anim. Ecol. 46: 195-212.

KREBS C.J. 1989: Ecological Methodology. Harper \& Row, New York, $624 \mathrm{pp}$.

LEATHER S.R. 1985: Oviposition preferences in relation to larval growth rates and survival in the pine beauty moth, Panolis flammea. Ecol. Entomol. 10: 213-217.

Mackay D.A. \& Singer M.C. 1982: The basis of an apparent preference for isolated host plants by ovipositing Euptychia libye butterflies. Ecol. Entomol. 7: 299-303.

Mattson W.J. 1980: Herbivory in relation to plant nitrogen content. Annu. Rev. Ecol. Syst. 11: 119-161.

McKaY H.V. 1991: Egglaying requirements of woodland butterflies: Brimstones (Gonepteryx rhamni) and Alder Buckthorn (Frangula alnus). J. Appl. Ecol. 28: 731-743.

MurPHY D.D. 1983: Nectar sources as constraints on the distribution of egg masses by the checkerspot butterfly, Euphydryas chalcedona (Lepidoptera: Nymphalidae). Envir. Entomol. 12: 463-466.

OYEYele S.O. \& ZaLuCKI M.P. 1990: Cardiac glycosides and oviposition by Danaus plexippus on Asclepias fruticosa in Southeast Queensland (Australia), with notes on the effect of plant nitrogen content. Ecol. Entomol. 15: 177-185.

PORTER K. 1992: Eggs and egglaying. In Dennis R.L.H. (ed.): The Ecology of Butterflies in Britain. Oxford Science Publications, Oxford, pp. 46-72.

Pullin A.S. 1997: Habitat requirements of Lycaena dispar batavus and implications for re-establishment in England. J. Insect Conserv. 1: 177-185. 
Pullin A.S., McLean I.F.G. \& Webb M.R. 1995: Ecology and conservation of Lycaena dispar British and European perspectives. In Pullin A.S. (ed.): Ecology and Conservation of Butterflies. Chapman and Hall, London, pp. 50-164.

RAUSHER M.D. 1978: Search image for leaf shape in a butterfly Science (Washington) 200: 1071-1073.

RAUSHER M.D. 1979: Egg recognition: its advantage to a butterfly. Anim. Behav. 27: 1034-1040.

RaUSHER M.D. 1981: Host plant selection by Battus philenor butterflies: the roles of predation, nutrition and plant chemistry. Ecol. Monogr. 51: 1-20.

RAUSHER M.D. 1983: Alteration of oviposition behaviour by Battus philenor butterflies in response to variation in hostplant density. Ecology 64: 1028-1034.

RAVENSCROFT N.O.M. 1994: The feeding behaviour of Carterocephalus palaemon (Lepidoptera: Hesperiidae) caterpillars: does it avoid host defences or maximize nutrient intake? Ecol. Entomol. 19: 26-30.

ReNwiCK J.A.A. \& Chew F.S. 1994: Oviposition behaviour in Lepidoptera. Annu. Rev. Entomol. 39: 377-400.

Rothschild M. \& Schoonhoven L.M. 1977: Assessment of egg load by Pieris brassicae (Lepidoptera: Pieridae). Nature (London) 266: 352-355.

SCRIBER J.M. \& SLANSKY F. 1981: The nutritional ecology of immature insects. Annu. Rev. Entomol. 26: 183-211.

Shreeve T.G. 1986: Egglaying by the speckled wood butterfly (Pararge aegeria): the role of female behaviour, host plant abundance and temperature. Ecol. Entomol. 11: 229-236.

SINGER M.C. \& MANDRACCHIA J. 1982: On the failure of two butterfly species to respond to the presence of conspecific eggs prior to oviposition. Ecol. Entomol. 7: 327-330.

SLANSKY F. 1993: Nutritional ecology: The fundamental quest for nutrients. In Stamp N.E. \& Casey T.M. (eds): Caterpillars - Ecological and Evolutionary Constraints on Foraging. Chapman and Hall, London, pp. 29-91.

Soberón J.M., Cordero C.M., Benrey B.B., Parlange P.P, Garcla-Saez C. \& Berges G. 1988: Patterns of oviposition by Sandia xami (Lepidoptera, Lycaenidae) in relation to food plant apparency. Ecol. Entomol. 13: 71-79.

Southwood T.R.E. 1976: Ecological Methods - With Particular Reference to the Study of Insect Populations. Chapman and Hall, London.

STAMP N.E. \& Bowers M.D. 1990: Phenology of nutritional differences between new and mature leaves and its effect on caterpillar growth. Ecol. Entomol. 15: 447-454.
Stanton M.L. 1982: Searching in patchy environment: foodplant selection by Colias p. eriphyle butterflies. Ecology 63 : 839-853.

THOMAS A.T. \& HoDkinson I.D. 1991: Nitrogen, water stress and the feeding efficiency of Lepidopteran herbivores. J. Appl. Ecol. 28: 703-720.

Thomas C.D. 1985: The status and conservation of the butterfly Plebejus argus L. (Lepidoptera: Lycaenidae) in North West Britain. Biol. Conserv. 33: 29-51.

Thompson J.N. \& Pellmyr O. 1991: Evolution of oviposition behaviour and host preference in Lepidoptera. Annu. Rev. Entomol. 36: 65-89.

Vasconcellos Neto J. \& Monteiro R.F. 1993: Inspection and evaluation of host plant by the butterfly Mechanitis lysimnia (Nymph., Ithomiinae) before laying eggs: a mechanism to reduce intraspecific competition. Oecologica 95: 431-438.

WARREN M.S. 1984: The biology and status of the wood white butterfly, Leptidea sinapis (Lepidoptera, Pieridae) in the British Isles. Entomol. Gaz. 35: 207-223.

WARREN M.S. 1995: Managing local microclimates for the high brown fritillary, Argynnis adippe. In Pullin A.S. (ed.): Ecology and Conservation of Butterflies. Chapman and Hall, London, pp. 198-210.

WeBB M.R. 1995: Ecology and Conservation of the Large Copper Butterfly, Lycaena dispar batavus. Unpubl. PhD Thesis, Keele University, 202 pp.

Webi M.R. \& Pullin A.S. 1996: Larval survival in populations of the large copper butterfly, Lycaena dispar batavus. Ecography 19: 279-286.

WebB M.R. \& Pullin A.S. 1997: The Orange Argus - A history of the large copper butterfly in Britain. Br. Wildl. 9: 29-37.

WebB M.R. \& Pullin A.S. 1998: Effects of submergence by winter floods on diapausing caterpillars of a wetland butterfly, Lycaena dispar batavus. Ecol. Entomol. 23: 96-99.

WIKLUND C. 1977: Oviposition, feeding and spatial separation of breeding and foraging habitats in a population of Leptidea sinapis (Lepidoptera). Oikos 28: 56-68.

WIKLund C. 1984: Egglaying patterns in butterflies in relation to their phenology and the visual apparency and abundance of their host plants. Oecologia 63: 23-29.

ZAR J.H. 1996: Biostatistical Analysis. 3rd ed. Prentice Hall International Editions, New Jersey, 929 pp.

Received March 8, 1999; accepted December 6, 1999 